\title{
A Rare Association of Rheumatoid Arthritis with Crohn's Disease
}

\author{
Romatoid Artrit ve Crohn Hastalığı'nın Nadir Birlikteliği \\ Hatice Reşorlu, Erdem Akbal*, Ferhat Gökmen, Yılmaz Savaş \\ Çanakkale Onsekiz Mart University Faculty of Medicine, Department of Physical Medicine and Rehabilitation, Çanakkale, Turkey \\ *Çanakkale Onsekiz Mart University Faculty of Medicine, Department of Gastroenterology, Çanakkale, Turkey
}

\section{To the Editor;}

Crohn's disease (CD) is an chronic autoimmune inflammatory bowel disease (IBD) which may involve any part of the gastrointestinal system (GIS) (1). Although the rellationships among autoimmune diseases are known, association of rheumatoid arthritis (RA) and $C D$ is an extremely rare condition $(2,3)$.

A 50-year-old male patient who had the diagnosis of seropositive RA for 5 years, presented with the complaints of bloody diarrhea and abdominal pain. The RA treatment had been regulated as a combination of methotrexate, sülfasalazine and hydroxychloroquine, and the patient reported that he was regularly taking the medical therapy. In joint examination, metacarpophalangeal joint arthritis were found bilateral. No hand deformity was observed. In physical examination, there were no findings except tenderness in the lower abdominal quadrants. There was not any bacterial growth in the stool culture. The results of the colonoscopy, found inflammation in the ileum (Figure 1a, 1b). Histopathologic examination was compatible with CD. Anteroposterior hand radiography revealed narrowing in $3^{\text {rd }}$ and $4^{\text {th }}$ proximal interphalengeal joints (Figure 1c). Genu varum deformity was found in the knee and magnetic resonance imaging (MRI) revealed synovial hypertrophy. Biochemical analysis yielded sedimentation rate as $22 \mathrm{~mm} / \mathrm{h}$ (Reference range: $0-20 \mathrm{~mm} / \mathrm{h}$ ), C-reactive protein $1.21 \mathrm{mg} / \mathrm{dL}$ (reference range: 0-0.5 mg/dL), rheumatoid factor $(+)$ and anti cyclic citrullinated peptide (CCP) (+). Mesalazine and azathioprine were added to his treatment protocol. At follow-up, complaints of the patiens gradually regressed within 4 months.

Articular system involvement is commonly seen in IBD such as ulcerative colitis (UC) and CD. Axial and peripheral articular findings may commence before, concurrently or after the diagnosis of IBD. Peripheral arthritis is generally in form the oligoarticular involvement of the large joints. However, in a small portion of IBDs, an arthritis form may be seen, resembling rheumatoid arthritis and often affecting the small joints of the hand symmetrically and polyarticularly (4). Peripheral arthritis is reported in CD by $10-20 \%$ which is more frequent compared to UC (5). Our patient was diagnosed with $C D$, suggesting us the joint findings may be occured due to this condition. However, IBD arthritis is seronegative and never or rarely causes joint destruction compared to RA (5). In our patient, arthritis had begun about 5 years before GIS symptoms. According to 2010 American College of Rheumatology/European League Against Rheumatism criteria, positivity of anti CCP, RF antibodies, marked synovial hypertrophy in the knees on MRI and narrowing of the joint spacing found in our patient confirmed the diagnosis of RA. Our patient who could not describe an association between the exacerbation of $C D$ and arthritis gave positive response to RA treatment.
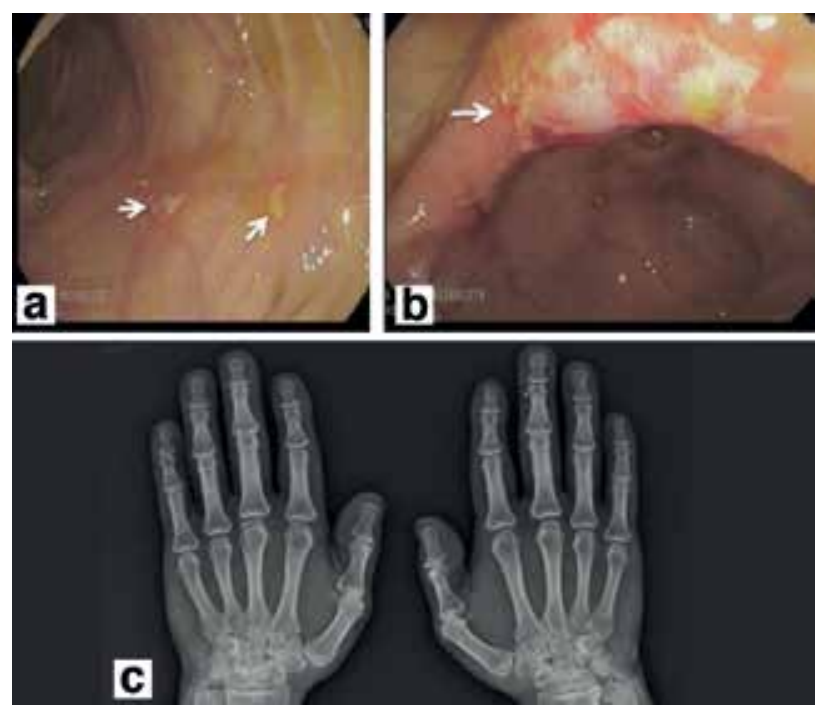

Figure 1. a, b) Show superficially localized ulcers in distal ileum in Crohn disease, c) reveals narrowing in proximal interphalengeal joints

Address for Correspondence/Yazışma Adresi: Hatice Reşorlu MD, Çanakkale Onsekiz Mart University Faculty of Medicine, Department of Physical Medicine and Rehabilitation, Çanakkale, Turkey Phone: +90 5054548721 E-mail: drresorlu@gmail.com Received/Geliş Tarihi: 15.02.2016 Accepted/Kabul Tarihi: 09.03.2016 
In the course of RA, colitis may develop due to intolerance against drugs (especially golden salts), systemic vasculitis, infections and intestinal amyloidosis (2). Based on the clinical and laboratory findings of our patient, we did not consider infection, vasculitis or amyloidosis. Furthermore, he was not using drugs that might affect the GIS.

Common genetic and immunologic mechanisms are involved in inflammation occurring in the joints and intestinal mucosa $(1,4)$. The most important factor among the genetic mechanisms is human leukocyte antigen B27 positivity (4). Whereas, among the immunologic mechanisms, anormal immune response developing against intestinal bacteria play an important role in different types of arthritis. It has been demosntrated in some animal models that inflammation is triggered by the activation of $\mathrm{T}$ cells in bacterial cell wall fragments (6). The activation of $T$ cells is predominant in patients with RA and CD. This may partly explain association of the two disease.

In conclusion; association of rheumatoid arthritis and CD is an extremely rare condition. Concurrence of inflammatory bowel findings and peripheral arthritis can make the diagnosis difficult. The persistence of RF and anti CCP antibodies in these patients is guiding for establishment of diagnosis. It is important to reach the correct diagnosis with a suspicious approach in order to provide adequate treatment in these patients. Further studies are warranted to enlighten the pathogenesis of this association.

Keywords: Rheumatoid arthritis, Crohn disease, complication Anahtar kelimeler: Romatoid artrit, Crohn hastalığı, komplikasyon

\section{Ethics}

Peer-review: Internally peer-reviewed.

\section{Authorship Contributions}

Surgical and Medical Practices: Hatice Reşorlu, Erdem Akbal, Concept: Hatice Reşorlu, Design: Erdem Akbal, Data Collection or Processing: Ferhat Gökmen, Analysis or Interpretation: Ferhat Gökmen, Yılmaz Savaş, Literature Search: Yılmaz Savaş, Writing: Hatice Reşorlu.

Conflict of Interest: No conflict of interest was declared by the authors.

Financial Disclosure: The authors declared that this study received no financial support.

\section{References}

1. Danese S, Semeraro S, Papa A, Roberto I, Scaldaferri F, Fedeli $\mathrm{G}$, et al. Extraintestinal manifestations in inflammatory bowel disease. World J Gastroenterol 2005;11:7227-36.

2. Toussirot E, Wendling D. Crohn's disease associated with seropositive rheumatoid arthritis. Clin Exp Rheumatol 1997;15:30711.

3. Georgiadis AN, Tzambouras N, Ioachim E, Tsianos EV, Agnantis $\mathrm{N}$, Drosos AA. Seropositive rheumatoid arthritis associated with Crohn's disease. Clin Exp Rheumatol 2003;21:363-5.

4. Danese S, Semeraro S, Papa A, Roberto I, Scaldaferri F, Fedeli $\mathrm{G}$, et al. Extraintestinal manifestations in inflammatory bowel disease. World J Gastroenterol 2005;11:7227-36.

5. Vavricka SR, Schoepfer A, Scharl M, Lakatos PL, Navarini A, Rogler G. Extraintestinal Manifestations of Inflammatory Bowel Disease. Inflamm Bowel Dis 2015;21:1982-92.

6. Aydin Y, Ozcakar L, Yildiz M, Akinci A. Liaison between rheumatoid arthritis and ulcerative colitis. Rheumatol Int 2003;23:47-8. 